\title{
Unsur Elemen tak Tereduksi (Irreducible Element) Realisme Magis Dalam Novel Bumi Karya Tere Liye
}

\section{Irreducible Element of Magical Realism in Tere Liye's Novel Bumi}

\author{
Ananda Farah Salsabila, Karkono* \\ Universitas Negeri Malang, Jl. Semarang No. 5 Malang, Jawa Timur, Indonesia \\ *Penulis korespondensi, Surel: karkono.fs@um.ac.id
}

Paper received: 02-01-2021; revised: 15-01-2021; accepted: 30-01-2021

\begin{abstract}
Abstrak
Realisme magis adalah sebuah teori yang dirumuskan oleh Wendy B. Faris mengenai narasi yang memadukan unsur fantasi dan realita. Istilah realisme magis lahir pada 1925 melalui dunia lukis dan diperkenalkan oleh Franz Roh, seorang kritikus seni Jerman. Novel Bumi karya Tere Liye yang terbit pada tahun 2014 mengangkat konsep realisme magis. Penulisan dalam novel ini mengandung petualangan imajinasi dimana para tokoh-tokoh utamanya dikisahkan bahwa mereka sedang berada dalam petualangan mencari jati diri mereka dan pencarian itu mereka lakukan hingga ke dunia paralel. Penelitian kualitatif ini menggunakan pendekatan kepustakaan. Data yang dikumpulkan berupa data verbal dan kebahasaan yang mengandung unsur Irreducible Element dalam sumber data berupa novel Bumi karya Tere Liye. Unsur Irreducible Element yang terdapat dalam narasi meliputi kemampuan magis tokoh-tokoh utama, seperti Raib yang dapat berubah menjadi tak kasat mata, Seli yang dapat memancarkan petir biru, dan Ali yang dapat berubah menjadi beruang raksasa. Dalam novel ini juga terdapat objek-objek magis seperti lorong berpindah, Buku Kehidupan, sarung tangan Klan Matahari, dan lain sebagainya. Keberadaan Dunia Paralel juga merupakan faktor yang memperkuat unsur Irreducible Element dalam novel ini.
\end{abstract}

Kata kunci: realisme magis, irreducible element, novel Bumi

\begin{abstract}
Magical realism is a theory by Wendy B. Faris that tells about a narrative that combines the elements of fantasy and reality. The term magical realism was created in 1925 throughout the world of painting and was introduced by Franz Roh, a German art critic. The novel Bumi by Tere Liye that was published in 2014 has the concept of magical realism in it. The writing in this novel contains an imaginary adventure where the main characters are trying to find their true self until they reach the parallel universe. This qualitative research uses a library research method. The data collected were verbal and linguistic data that contains an irreducible element in the data source that is the novel Bumi by Tere Liye. Irreducible element contained in the narrative includes the magical abilities of the main characters, such as Raib who can turn invisible, Seli who can radiate blue lightning, and Ali who can transform into a giant bear. There are also magical objects in this novel, such as the moving alley, The Book of Life, The Sun gloves, and others. The existence of a parallel universe is also a factor that strengthens the irreducible element in this novel.
\end{abstract}

Keywords: magical realism, irreducible element, Bumi novel

\section{Pendahuluan}

Realisme magis adalah genre fiksi suatu karya sastra yang mengangkat unsur-unsur di luar nalar manusia atau hal-hal magis yang berpadu dengan dunia nyata. Dalam genre fiksi ini, terdapat kesejajaran antara unsur-unsur fantasi dan realita, dua hal yang bertolak belakang tersebut terhubung oleh pandangan budaya atau kepercayaan dalam masyarakat. Realisme magis yang merupakan genre sastra ini berasal dari dikembangkannya suatu lukisan bergenre 
post ekspresionis pada tahun 1920 di Jerman dan pada tahun 1930 di Amerika Latin. Konsep ini awalnya diciptakan oleh Franz Roh, seorang kritikus seni Jerman pada 1920 -an dan 1930an (Bowers, 2004). Dalam realisme magis, sesuatu yang supernatural dapat terjadi dalam keadaan yang sama dengan kehidupan duniawi. Peristiwa "melampaui batas" terjadi sebagai bagian dari kehidupan nyata itu sendiri. Kehadiran unsur-unsur magis benar-benar terjadi dan tidak dapat dijelaskan oleh pengetahuan duniawi manusia. Maka, realisme magis mampu menghapus sekat antara hal-hal magis dan realis (Srikanth, 2014). Dalam realisme magis selalu terjadi interaksi antara pembaca dan narasi magis yang menyebabkan para pembaca memercayai bahwa hal-hal magis tersebut memang ada di sekitar mereka, hal ini menyebabkan segala hal yang sebelumnya dianggap ajaib, kini tampak normal dalam narasi tersebut (Hasanah, Mega, \& Vincentia, 2018). Pada awalnya keberadaan irreducible element mengganggu perspektif logika, namun kini keberadaan irreducible element telah mengalami normalisasi dalam narasi sehingga peristiwa-peristiwa magis tersebut berubah menjadi peristiwa umum atau wajar dalam kehidupan tokoh (Sie, 2020).

Realisme magis lahir di kesusastraan Indonesia pada tahun 1990-an, realisme magis sebagai konsepsi kesusastraan yang mendunia mulai menyebarkan pengaruhnya pada karyakarya sastra Indonesia, antara lain cerpen "Misteri Kota Ningi" karya Seno Gumira Ajidarma, novel "Cantik Itu Luka" karya Eka Kurniawan, dan novel "Simple Miracles : Doa dan Arwah" karya Ayu Utami yang menunjukkan perpaduan unsur kenyataan dan magis dalam prosa sastra Indonesia. Salah satu ciri realisme magis adalah munculnya suatu konsep dan paham berunsur magis yang bermula dari karya legenda, dongeng, dan mitologi yang tumbuh bersamaan dengan masyarakat. Novel Bumi karya Tere Liye yang terbit pada tahun 2014 juga mengangkat konsep realisme magis. Dalam novel ini, para tokoh dikisahkan bahwa mereka sedang berada dalam petualangan mencari jati diri mereka dan pencarian itu mereka lakukan hingga ke dunia paralel. Tokoh utama dalam novel Bumi adalah Raib, ia dapat berubah menjadi tak kasat mata. Begitu pula dua teman Raib, Seli yang dapat memancarkan petir biru dan Ali yang dapat bertransformasi menjadi beruang raksasa. Munculnya nilai magis dalam cerita ini menggambarkan bahwa kelanjutan dari cerita ini membawa para pembaca menuju dunia magis yang penuh dengan elemen mistis dan kemampuan magis para tokoh. Berdasarkan kerangka penelitian yang telah dijabarkan, tujuan dari ditulisnya penelitian ini adalah guna menganalisis peristiwa realisme magis yang digambarkan dalam novel Bumi karya Tere Liye.

Tere Liye merupakan seorang penulis yang terkenal dengan karya-karya bergenre keluarga, romantik, dan politik. Beberapa karyanya yang terkenal antara lain Bidadaribidadari Surga dan Hafalan Shalat Delisa yang mengangkat genre keluarga, Kau, Aku, dan Sepucuk Angpau Merah dan Sunset Bersama Rosie yang mengangkat genre romantik, juga Negeri Para Bedebah yang mengangkat genre politik. Penulisan karya-karya Tere Liye pada umumnya terfokus pada isu-isu realistis yang terjadi di lingkungan masyarakat sekitar, namun dalam penulisan serial Bumi atau Dunia Paralel, Tere Liye memilih genre fantasi yang mengarah ke realisme magis. Serial Dunia Paralel yang kini terdiri dari 11 buku (Bumi, Bulan, Matahari, Bintang, Ceros dan Batozar, Komet, Komet Minor, Selena, Nebula, Lumpu, dan Si Putih) dan masih berlanjut ini mendapat apresiasi yang tinggi di kalangan anak muda. Tingginya ketertarikan pembaca terhadap genre fantasi menyebabkan keingintahuan yang tinggi terhadap kualitas penulis-penulis dalam negeri terhadap penulisan karya dengan genre tersebut. Tingginya apresiasi para pembaca terhadap serial Dunia Paralel karya Tere Liye membuktikan bahwa kualitas genre fantasi dalam serial tersebut sangat luar biasa. Tiga buku 
pertama dari serial Dunia Paralel, yakni Bumi, Bulan, dan Matahari telah diterjemahkan ke dalam bahasa Inggris. Serial ini mendapat penilaian kurang lebih 4,3/5 di laman Goodreads.

Proses penganalisisan objek dalam penelitian ini menggunakan teori realisme magis milik Wendy B. Faris. Realisme magis adalah suatu ideologi yang menciptakan berbagai hal yang bersifat magis yang bermula dari literasi berupa mitologi, dongeng, dan legenda yang tumbuh bersamaan dengan masyarakat (Faris, 2004). Suatu narasi dapat dikatakan sebagai literasi berunsur realisme magis bukan hanya karena narasi tersebut mengangkat kisah-kisah magis yang bersumber dari mitos ataupun legenda, namun juga berdasarkan karakteristik realisme magis yang ada dalam narasi tersebut, yaitu irreducible element, phenomenal world, unsettling doubt, merging realms, dan disruption of time, space, and identity. Dalam penelitian ini, peneliti memfokuskan penelitian mengenai satu dari lima karakteristik realisme magis, yakni irreducible element.

Elemen magis dalam irreducible element digolongkan dalam empat kategori, yaitu yang bersumber pada objek magis, bunyi magis, tempat terjadinya peristiwa magis, dan karakteristik tokoh yang memiliki kemampuan khusus yang tidak dapat dipahami oleh logika. Objek magis merupakan suatu benda yang berada dalam alam kenyataan dan dapat disadari kehadirannya oleh pancaindra. Objek-objek magis ini biasanya terlihat normal seperti bendabenda pada umumnya, namun memiliki suatu unsur magis tertentu yang menimbulkan suatu keraguan dan pertanyaan dalam diri para pembaca. Bunyi magis difokuskan pada suara yang dapat didengar, namun pada hal ini suara tersebut tidak berasal dari benda hidup, benda mati, maupun suatu tempat yang wajar. Suara-suara magis ini dimunculkan dalam narasi novel sebagai suatu tanda dari kehadiran dari peristiwa dan makhluk magis. Karakteristik tokoh merupakan wujud dari sifat-sifat para tokoh dalam cerita. Sifat-sifat para tokoh dalam lingkungan sekitarnya digambarkan bahwa mereka telah menyadari atau mengalami suatu peristiwa magis yang berpengaruh pada tingkah laku dan pola pikirnya.

Fokus dalam penelitian ini adalah mengenai penafsiran irreducible element dalam novel Bumi karya Tere Liye. Penelitian ini juga difokuskan mengenai penjelasan di balik kutipankutipan narasi dalam novel Bumi yang terklasifikasi dalam unsur irreducible element. Kutipankutipan narasi mengenai irreducible element yang diambil antara lain adalah kutipan yang menunjukkan bahwa tokoh-tokoh dalam novel Bumi memiliki kekuatan atau elemen magis yang tidak wajar yang dianggap irasional. Kutipan-kutipan narasi dalam novel Bumi ini dianalisis dan dijelaskan korelasinya dengan teori realisme magis.

\section{Metode}

Penelitian ini menggunakan pendekatan kepustakaan, yakni proses pencarian data penelitian menggunakan metode membaca dan mencatat objek penelitian sehingga dapat mengumpulkan data-data kepustakaan dari objek yang dianalisis. Dalam hal ini, data yang dikumpulkan berupa kutipan narasi yang mengandung unsur Irreducible Element dalam novel Bumi karya Tere Liye. Jenis data dalam penelitian ini adalah jenis data kualitatif, maka pengumpulan data tidak dihasilkan dalam bentuk angka, melainkan dalam bentuk catatancatatan tertentu dan naskah wawancara . Penelitian ini menggunakan novel Bumi sebagai sumber data dan analisis data verbal dan kebahasaan yang mengangkat unsur irreducible element dalam novel Bumi sebagai data. Orientasi teoritis dalam penelitian ini adalah teori realisme magis yang difokuskan pada satu unsur, yakni irreducible element. Teori realisme magis dirumuskan oleh Wendy B. Faris. Istilah realisme magis lahir pada 1925 melalui dunia 
lukis dan diperkenalkan oleh Franz Roh, seorang kritikus seni Jerman. Roh menjelaskan bahwa suatu lukisan realis harus memunculkan misteri yang konkret sebagai aspek sakral dalam lukisan realisme magis. Penelitian ini menggunakan instrumen berupa kerangka pokok yang mengelompokkan kutipan narasi yang mengandung irreducible element berdasarkan karakteristik tokoh, objek magis, dan fenomena magis, kemudian juga dijelaskan secara mendetail dan dikorelasikan dengan teori-teori realisme magis dari para ahli mengenai makna magis yang melatarbelakangi narasi dalam novel tersebut. Analisis data merupakan proses penyusunan data yang telah didapat peneliti melalui catatan lapangan atau proses analisis tertentu. Metode yang dijalankan dalam analisis data adalah mengelompokkan data dalam kategori-kategori yang telah ditentukan, menganalisis data dalam tiap kategori, memilah data yang penting, dan diakhiri dengan membuat kesimpulan dari keseluruhan analisis data yang telah dilakukan.

\section{Hasil dan Pembahasan}

\subsection{Hal-Hal yang Melatarbelakangi Munculnya Unsur Irreducible Element dalam Novel Bumi Karya Tere Liye}

Salah satu alasan terciptanya novel Bumi karya Tere Liye adalah maraknya novel dengan genre fantasy young adult di barat yang dimulai sekitar tahun 2010 hingga saat ini. Beberapa contoh novel barat bergenre young adult fantasy yang mengandung unsur realisme magis yang terbit pada awal tahun 2010 hingga saat ini adalah seri The Infernal Devices karya Cassandra Clare, seri The Heroes of Olympus karya Rick Riordan, dan seri Lorien Legacies karya Pittacus Lore. Pada saat itu penulis-penulis Indonesia telah menerbitkan beberapa novel yang mengangkat unsur realisme magis, yakni Simple Miracles: Doa dan Arwah karya Ayu Utami, cerpen Misteri Kota Ningi karya Seno Gumira Ajidarma, dan Cantik Itu Luka karya Eka Kurniawan yang terbit pada 2002. Karya-karya yang telah disebutkan tersebut mengangkat unsur realisme magis, namun konteks realisme magis yang dimaksud adalah realisme magis yang mengarah ke kepercayaan dan mitos yang mengelilingi kehidupan masyarakat, sedangkan novel Bumi karya Tere Liye mengangkat unsur realisme magis yang lebih mengarah ke genre fantasi. Minat membaca remaja Indonesia juga menjadi faktor yang melatarbelakangi ditulisnya novel ini. Sebagian besar remaja cenderung berimajinasi bahwa mereka dapat memiliki suatu kemampuan magis atau bahkan berpetualang menuju suatu alam magis yang ada dalam khayalan mereka.

Latar belakang munculnya unsur irreducible element dalam novel Bumi tidak hanya hadir untuk memenuhi keinginan pembaca terhadap bahan bacaan yang mengangkat genre realisme magis, karya sastra memiliki fungsi untuk mengabadikan suatu kebudayaan masyarakat dari berbagai era, juga untuk membuktikan bahwa suatu masyarakat tidak pernah terlepas dari konteks-konteks kepercayaan magis walaupun ia hidup dalam era modern (Junus, 1986). Pada dasarnya, masyarakat akan kembali memusatkan fokusnya pada hal-hal magis jika hal-hal ilmiah tidak lagi mampu untuk menjawab rasa ingin tahunya. Adanya keinginan para pembaca untuk membaca karya-karya sastra yang mengangkat genre realisme magis bukan hanya disebabkan karena pengetahuan ilmiah yang tidak lagi mampu menjawab rasa ingin tahu mereka, hal ini disebabkan karena sifat dari realisme magis itu sendiri. Ideologi dari realisme magis selalu ada dalam setiap periode waktu karena realisme magis bersumber dari literasi berupa mitologi, dongeng, dan legenda yang terjadi di masa lampau. Pada dasarnya periode waktu terus berjalan dan masa kini nantinya menjadi masa lampau, maka literasiliterasi di masa mendatang selalu memiliki unsur realisme magis di dalamnya dan topik 
realisme magis dalam narasi-narasi tersebut mengalami evolusi berdasarkan literasi-literasi yang mengangkat unsur realisme magis di masa lampau pada era tersebut.

\subsection{Perspektif Realisme Magis Dalam Novel Bumi Karya Tere Liye}

Pandangan mengenai keberadaan genre realisme magis pada karya sastra menurut para pembaca yang didominasi oleh remaja memiliki nilai yang cukup tinggi. Para remaja yang sedang menemukan jati diri selalu memiliki pola pikir dan pertanyaan-pertanyaan unik. Selalu muncul pertanyaan-pertanyaan seperti "bagaimana jika" dan "apakah ada" mengenai hal-hal magis, mayoritas dari pertanyaan ini menyinggung konteks realisme magis karena pada dasarnya mereka hidup di lingkungan yang berpegang teguh pada hukum alam, maka pertanyaan-pertanyaan mengenai keberadaan hal-hal supernatural secara tidak langsung selalu muncul.

Tokoh-tokoh utama dalam novel Bumi karya Tere Liye adalah tiga orang remaja yang memiliki kemampuan magis. Pemilihan tiga tokoh utama oleh Tere Liye ini semakin memperkuat bukti bahwa para remaja memiliki rasa keingintahuan yang kuat dan cenderung tertarik dengan hal-hal yang tidak dapat dijelaskan oleh logika. Realisme magis merupakan suatu ideologi yang menciptakan segala hal yang bersifat magis, hal tersebut dapat dibuktikan dalam kutipan narasi berikut.

“... Itulah kali pertama kekuatan itu muncul. Kekuatan yang tidak pernah berhasil aku mengerti hingga hari ini, kekuatan yang kurahasiakan dari siapapun hingga usiaku lima belas. Aku tinggal menutupi wajahku dengan kedua telapak tangan, berniat bersembunyi, maka seketika, seluruh tubuhku tidak terlihat. Lenyap." (Liye, 2014:2)

Raib, tokoh utama dalam novel Bumi, dikisahkan memiliki kemampuan khusus untuk menghilang. Adanya manusia yang dapat berubah menjadi tak kasat mata tidak bisa dijelaskan secara ilmiah. Namun ada beberapa orang yang memercayai keberadaan makhluk tak kasat mata, walaupun dalam hal ini terdapat perbedaan konteks mengenai makhluk tak kasat mata, tetapi sebuah pemikiran tentang keberadaan hal-hal magis tak kasat mata yang hidup bersamaan dengan manusia secara tidak langsung memang ada dan narasi di atas sangat memperkuat kesan magis dalam novel ini.

Hal-hal magis tidak selalu mengenai subjek yang menciptakan peristiwa magis, tetapi juga mengenai objek penyebab terjadinya peristiwa magis. Tokoh-tokoh tertentu dalam suatu novel tidak mampu mempraktikkan hal-hal magis jika ia tidak memiliki objek untuk menciptakan peristiwa magis tersebut. Dalam novel Bumi, Raib, Seli, dan Ali tidak sengaja memasuki dunia Klan Bulan seperti dalam narasi berikut.

“"Maaf, kami tidak salah masuk kamar." Aku menggeleng. "Tadi kami berada di kamarku, di rumahku, lantas tiba-tiba saja kami sudah pindah ke kamar ini." Ayah si kecil mendekat. "Apakah kalian sebelumnya sedang menggunakan lorong berpindah?"'" (Liye, 2014:163)

Dalam narasi tersebut dikisahkan bahwa Raib, Seli, dan Ali tidak sengaja memasuki dunia Klan Bulan melalui lorong berpindah. Lorong berpindah berperan sebagai pintu di sekat antar dunia paralel tersebut. Objek magis merupakan hal yang sangat sakral dan penting dalam proses terjadinya peristiwa magis karena objek magis mampu memecah batas antar dunia paralel. Pengaruh mitos suatu budaya dalam ide penciptaan lorong berpindah di narasi novel Bumi dapat dikaitkan dengan realisme magis yang dipahami sebagai ekspresi estetika 
primitivisme canggih yang digunakan oleh para penulis untuk menyalurkan ide-ide tulisannya mengenai identitas dan emansipasi budaya (Warnes, 2009). Elemen realisme magis yang ditulis dalam karya Carpentier, García Márquez, Rulfo, dan Asturias merupakan bukti dari dikembangkannya suatu keinginan para penulis untuk mengembalikan elemen-elemen magis dengan sentuhan mitos-mitos tertentu.

Probabilitas terjadinya pengulangan mitos atau peristiwa magis dalam narasi realisme magis sangatlah tinggi, hal ini disebabkan luasnya konsepsi kepercayaan magis dalam lingkup kehidupan masyarakat karena setiap negara memiliki kisah-kisah magis yang beragam yang kemudian dijadikan sebuah citra negara tersebut (Shaw dalam Hart \& Ouyang, 2005). Terciptanya narasi magis dalam novel Bumi juga disebabkan karena kisah mengenai sihir magis yang tumbuh di kehidupan masyarakat Indonesia. Setiap suku di Indonesia memiliki kepercayaan masing-masing terhadap mitos-mitos tertentu, mitos-mitos magis ini tidak hanya tumbuh dalam lingkungan suku yang memercayai keberadaannya, mitos-mitos ini menyebar luas menuju masyarakat luar secara lisan. Tersebarnya mitos-mitos ini menginspirasi para penulis untuk menciptakan narasi-narasi magis yang memiliki elemen sihir, seperti Raib yang dapat berubah menjadi tak kasat mata, Seli yang dapat memancarkan petir biru, dan Ali yang dapat berubah menjadi beruang raksasa.

Dunia realitas dan dunia magis tidak selalu bertentangan, jika dilihat lebih dalam, kedua dunia yang berkontradiksi tersebut berjalan berdampingan tanpa menimbulkan pertanyaan tentang asal usul masing-masing dunia (Chanady, 2019). Raib yang merupakan Klan Bulan mampu melihat makhluk-mahkluk Klan Bulan walaupun ia sedang berada di dunia Klan Bumi, sedangakan kedua orang tua angkatnya yang benar-benar seorang Klan Bumi dan tidak mengetahui keberadaan dunia paralel, maka alat indra dan alam bawah sadar mereka mengendalikan pemikiran dan apa yang mereka pandang menjadi suatu hal yang normal bagi mereka. Kedua orang tua Raib tidak dapat melihat Si Hitam karena kucing itu merupakan Klan Bulan.

Dalam realisme magis selalu terjadi interaksi antara pembaca dan narasi magis yang menyebabkan para pembaca memercayai bahwa hal-hal magis tersebut memang ada di sekitar mereka. Hal ini menyebabkan segala hal yang sebelumnya dianggap ajaib, kini tampak normal dalam narasi tersebut (Hasanah dkk, 2018).

"Ali, tubuh Ali membesar berkali-kali lipat. Dia meraung lagi, lebih kencang dan mengerikan, membuat dinding ruangan bergetar. Tangannya membesar, kakinya membesar, dan seluruh tubuhnya dibungkus dengan cepat oleh bulu tebal berwarna hitam.

Hanya dalam hitungan detik, Ali berubah menjadi beruang dengan tinggi badan menyentuh langit-langit ruangan. Kuku-kuku panjang dan tajam muncul. Tangannya bahkan sebesar orang dewasa. Matanya merah. Taring berlumuran ludah keluar dari mulutnya." (Liye, 2014:364)

Pada narasi sebelumnya dijelaskan bahwa Klan Bumi tidak memiliki kemampuan khusus layaknya klan yang lain dan ilmu pengetahuan mereka sangat terbatas, namun dalam kutipan narasi di atas Ali membuktikan bahwa Klan Bumi juga memiliki kemampuan khusus. Ali, seorang Klan Bumi, menciptakan peristiwa magis pertamanya. Hal ini menimbulkan pertanyaan bahwa barangkali memang ada hal-hal magis di kehidupan para pembaca, namun keberadaannya memudar karena tidak ada yang secara total memercayai keberadaan hal-hal magis tersebut. 
Pada awalnya, keberadaan irreducible element mengganggu perspektif logika. Berbeda dengan saat ini, kini keberadaan irreducible element telah mengalami normalisasi dalam narasi sehingga peristiwa-peristiwa magis tersebut berubah menjadi peristiwa wajar dalam kehidupan tokoh (Sie, 2020).

"Aku gemetar menyaksikan tubuh Seli dibalut listrik. Percikan api membungkus badannya. Letupan cahaya merambat hingga leher, kepala, rambut. Sedetik berlalu, Seli menghantamkan tangannya ke tanah, seluruh aliran listrik itu mengalir melewati tangannya, masuk ke dalam tanah, kemudian hilang tak bersisa." (Liye, 2014:124)

Meskipun sedari kecil Raib telah terbiasa dengan hal-hal magis yang diciptakannya, namun Raib tetap terkejut ketika ia menyaksikan tubuh Seli yang dibalut listrik dan tetap baikbaik saja. Raib tidak pernah bertemu dengan orang lain yang memiliki kemampuan khusus. Kemampuan khusus Raib untuk berubah menjadi tak kasat mata merupakan suatu hal yang wajar untuknya karena ia telah menjalani 15 tahun hidupnya bersamaan dengan kemampuan magisnya. Keterkejutan Raib ketika ia menyaksikan Seli melakukan sebuah peristiwa magis secara tidak langsung juga Raib pandang sebagai suatu kewajaran.

Indra manusia tidak dapat menjangkau dunia magis dan keberadaan mutlaknya berada di zona abu-abu karena semuanya bergantung pada kepercayaan pribadi atau masyarakat tertentu (Sari, 2019). Dalam novel Bumi, hanya klan-klan tertentu saja yang mampu pergi menuju dunia klan lain, mereka memiliki lorong berpindah yang berperan sebagai portal antar dimensi. Dengan adanya lorong berpindah, maka manusia yang tidak memiliki kemampuan khusus pun dapat pergi menuju dunia klan lain, namun semua itu kembali lagi pada konteks kepercayaan dan pengetahuan mereka mengenai keberadaan dimensi lain ini. Maka dari itu keberadaan dunia magis dianggap berada dalam zona abu-abu karena hanya orang-orang yang memercayai dan memiliki pengetahuan tentang keberadaan dunia paralel yang dapat pergi menuju dimensi lain.

Adanya dunia paralel dan portal antar dimensi merupakan suatu ketidakmungkinan karena sangat bertolak belakang dengan konsep kenyataan. Sebagian besar elemen-elemen dalam kisah fantasi, seperti tokoh dan tempat dalam narasi, tidak benar-benar ada dalam kehidupan nyata dan cenderung menciptakan hal-hal yang bersifat unik dan mengundang pertanyaan (Kurniawan dalam Kapitan dkk, 2018). Hukum alam tidak mampu menjawab pertanyaan tentang keberadaan dunia paralel dan lorong berpindah dalam novel Bumi. Telah terdapat beberapa teori mengenai keberadaan dunia paralel, namun teori-teori tersebut lebih condong ke arah konspirasi yang kebenarannya masih dipertanyakan. Hingga kini, belum ada penelitian ataupun teori yang mampu membuktikan keberadaan dunia paralel, maka sebuah ide mengenai dunia paralel dianggap hanya karangan belaka.

Dalam sekat-sekat yang membatasi antara kenyataan dan khayalan dalam narasi fantasi sangat samar, fenomena yang berkontradiksi dengan logika seakan mampu meleburkan kenyataan dengan keanehan yang tidak selaras dengan hukum alam (Dewi, 2013). Semakin sering para pembaca membaca tentang detail dunia paralel dalam narasi, maka dunia paralel dipandang sebagai hal yang normal karena secara tidak langsung para pembaca telah mengetahui detail tertentu mengenai dunia paralel berdasarkan apa yang tertulis dalam narasi tersebut dan alam bawah sadar mereka memproses detail tersebut menjadi latar belakang suatu hal tadinya tidak mungkin menjadi sangat wajar. Para pembaca tentu masih bisa membedakan antara kenyataan dan khayalan secara umum, namun pandangan mereka 
mengenai keberadaan dunia paralel telah mereka anggap sebagai hal yang wajar dalam konteks khayalan.

\subsection{Latar Belakang Karakteristik Dan Detail Irreducible Element Pada Tokoh- Tokoh Utama Dalam Novel Bumi Karya Tere Liye}

Raib

Raib adalah seorang remaja berusia lima belas tahun dari Klan Bulan. Klan Bulan merupakan sekelompok manusia berkemampuan khusus yang hidup di dunia paralel yang terletak di Bumi, namun dunia antara Klan Bulan dan Klan Bumi tidak saling bersentuhan satu sama lain karena terdapat sekat tak kasat mata yang memisahkan dua dunia tersebut.

Irreducible element dalam sebuah karya sastra mampu menciptakan narasi-narasi yang penuh dengan elemen magis, elemen magis ini dimunculkan tanpa mampu dicerna oleh perspektif alat indra para pembaca, elemen magis juga dikisahkan dengan cara yang "normal" seakan elemen tersebut hanyalah peristiwa wajar yang dapat dialami oleh siapapun (Faris, 2004). Narasi yang memiliki irreducible element selalu dituliskan secara rinci, hal ini menyebabkan para pembaca tidak lagi mempertanyakan bagaimana fenomena-fenomena magis dalam narasi tersebut dapat terjadi jika disangkutpautkan dengan logika karena sang penulis telah menulis latar belakang dari fenomena magis tersebut dan para pembaca mencari korelasi antar logika mereka dengan latar belakang fenomena magis. Dalam novel Bumi, dijelaskan latar belakang elemen magis secara rinci, seperti asal-usul Raib yang menyebabkan ia dapat berubah menjadi tak kasat mata.

Pada awal narasi dalam novel, dikisahkan bahwa Raib tinggal bersama kedua orang tuanya di Bumi yang kemudian diketahui bahwa mereka adalah orang tua angkat Raib, kedua orang tua kandung Raib berasal dari keturunan murni Klan Bulan dan Raib adalah Putri Bulan. Raib memiliki kemampuan magis untuk berubah menjadi tak kasat mata, melakukan pukulan berdentum, menyembuhkan luka, berkomunikasi dengan alam disekitarnya, melakukan teleportasi, dan lain sebagainya. Anggota Klan Bulan hanya menguasai satu jenis kemampuan dan hanya keturunan murni Klan Bulan yang mampu menguasai seluruh kemampuan Klan Bulan.

Selain kemampuan-kemampuan magis tersebut, Raib juga memiliki sebuah objek magis yang disebut dengan Buku Kehidupan yang dapat membuka sekat antar dunia paralel. Realisme magis terbagi atas dua kategori. Pertama, realisme magis sebagai kemampuan seniman dan sastrawan untuk mengungkap resolusi spiritual dari kenyataan untuk mendeskripsikan secara rinci elemen-elemen keajaiban yang membentuknya, sehingga hukum alam tidak dapat menjelaskan unsur irasional yang terbentuk dalam realisme magis. Kedua, realisme magis sebagai kode representasi yang menjelaskan konstruksi budaya di mana garis waktu historis modernitas berjalan berdampingan dengan impresi supernatural (Perez \& Chevalier, 2014). Hanya orang-orang terpilih saja yang mampu memiliki Buku Kehidupan, dalam hal ini adalah keturunan murni Klan Bulan. Hal ini dapat dikorelasikan dengan warisan turun-temurun suatu budaya. Seseorang tentu saja tidak dapat sepenuhnya memahami konteks suatu budaya jika ia tidak tumbuh dengan ilmu pengetahuan yang diwariskan oleh budaya tersebut, maka hanya orang-orang tertentu yang tumbuh dalam lingkungan budaya tersebut yang mendapat warisan ilmu pengetahuan budaya tersebut secara utuh, layaknya Buku Kehidupan yang hanya mampu dimiliki oleh keturunan murni Klan Bulan. 
Kemampuan Raib untuk berubah menjadi tak kasat mata merupakan salah satu ciri dari irreducible element, yakni karakteristik tokoh yang memiliki pengaruh magis. Kemampuan Raib menimbulkan pertanyaan bagi para pembaca karena pemikiran tentang adanya kemampuan untuk berubah menjadi tak kasat mata tidak pernah dijumpai oleh pembaca dalam kesehariannya, maka unsur irreducible element dalam novel Bumi pertama kali muncul ketika kemampuan magis Raib diceritakan dalam narasi novel tersebut. Irreducible element merupakan elemen insidental, yakni elemen yang hanya terjadi dalam waktu-waktu tertentu atau tidak terjadi secara konstan (Todorov dalam Faris, 2004). Dalam narasi, Raib tidak terus menerus menggunakan kemampuan magisnya, ia hanya menggunakan kemampuan magisnya ketika ia berada dalam keadaan terdesak yang memaksanya harus menggunakan kemampuan magisnya.

Kedua kucing Raib, Si Hitam dan Si Putih, merupakan perwujudan hal nyata dan hal magis. Kepercayaan merupakan salah satu faktor yang membatasi antara dunia nyata dan dunia magis. Kedua orang tua Raib memercayai bahwa Raib hanya memiliki 1 ekor kucing alihalih 2 ekor kucing. Ketika papa Raib bertanya pada Raib mengenai nama kucing miliknya, Raib menjawab "Si Hitam dan si Putih" yang berarti ia memiliki 2 ekor kucing. Bertolak belakang dengan apa yang dilihat dan dipercayai oleh papa Raib, maka papa Raib bertanya lagi "Si Hitam atau si Putih, maksudmu?", kata "atau" di sini membuktikan bahwa papa Raib yakin bahwa di sana hanya ada 1 ekor kucing. Perbedaan perspektif ini memicu adanya peristiwa magis, namun kedua orang tua Raib menganggap bahwa putri mereka yang saat itu berusia 9 tahun hanya berimajinasi tentang keberadaan satu kucingnya yang lain.

Kemampuan khusus Raib untuk berubah menjadi tak kasat mata tidak hanya dapat ia lakukan pada dirinya sendiri, Raib juga dapat mengubah benda apapun yang ia inginkan menjadi tak kasat mata. Hal tersebut dapat dibuktikan dalam narasi berikut.

“... Aku menatap buku PR itu, mengacungkan jemari, berseru dalam hati.

Menghilanglah!

Buku PR itu lenyap.

Aku menahan napas, juga Seli di sebelahku.

Satu detik berlalu. Tidak terjadi apa pun. Dua detik, empat detik, aku menoleh ke Ali.

Bagaimana ini? Ali tetap menunggu dengan yakin. Delapan detik. Aduh, bagaimana kalau keliru? Seli ikut menatap Ali. Kenapa pula kami harus percaya pada genius biang kerok ini? Suara seperti gelembung air meletus terdengar. Buku PRku kembali." (Liye, 2014:159)

Tidak hanya dapat membuat benda-benda menjadi tak kasat mata, Raib juga dapat mengembalikan benda-benda tersebut pada wujud awalnya. Saat buku tugas matematika Raib kembali, terdengar suara seperti gelembung air yang meletus. Suara magis ini merupakan bukti bahwa buku tugas matematika raib telah berpindah dari satu tempat ke tempat lain melalui suatu gerbang tak kasat mata. Kemampuan Raib yang tidak terbatas hanya untuk dirinya sendiri ini semakin memperkuat unsur magis dalam novel ini, terlebih lagi kemampuannya untuk membuat suatu benda berteleportasi.

Seli

Seli adalah seorang remaja berusia lima belas tahun dari Klan Matahari. Sebagian anggota Klan Matahari bermigrasi menuju dunia Klan Bumi setelah perang antar klan ribuan tahun yang lalu. Seli merupakan keturunan generasi Klan Matahari ke-30 sejak peristiwa migrasi Klan Matahari. Seli mampu memancarkan petir biru, petir biru merupakan petir 
terkuat di Klan Matahari. Selain memancarkan petir, Seli juga dapat terbang dan melakukan telekinesis. Seli juga mampu mengubah rasa sakit menjadi kekuatan yang berlipat ganda ketika ia menggunakan sarung tangan Klan Matahari.

Seli pertama kali diceritakan menciptakan peristiwa magis ketika Raib tidak sengaja menyaksikan Seli sedang memegang dua kabel listrik hingga tubuhnya dibalut listrik, namun Seli mampu mengalirkan listrik tersebut ke dalam tanah agar tidak membahayakan orang lain. Sebuah pemikiran mengenai manusia yang dapat mengendalikan listrik dengan dua tangan kosong merupakan suatu ketidakmungkinan. Seli adalah karakter kedua yang memiliki kemampuan magis dalam novel ini.

Berbeda dengan Raib yang masih mempelajari kemampuan magisnya sesuai kehendaknya, Seli tampak sudah menguasai kemampuan magisnya. Hal ini membuktikan bahwa Seli yang telah dapat mengendalikan kemampuan magisnya tersebut telah mengalami peristiwa magis jauh sebelum Raib menyadari kemampuan magisnya.

"'Kamu bisa menunjukkan sesuatu, Seli? Agar istriku percaya." Ilo menoleh ke arah Seli.

Aku menerjemahkannya kepada Seli. Kami sudah hampir selesai makan.

"Sesuatu apa?" Seli bertanya padaku, tidak mengerti.

"Mungkin seperti menggerakkan benda-benda." Aku menebak maksud Ilo.

Seli mengangguk. Dia meletakkan sendoknya. Diam sejenak, berkonsentrasi, lantas mengangkat tangan, mengarahkannya ke gelas kosong milik Ali di seberang meja. Gelas itu perlahan-lahan terangkat ke udara." (Liye, 2014:282)

Pemahaman yang kuat mengenai realisme magis harus digambarkan secara rinci hingga orang lain mampu memandangnya sebagai panorama luas dengan detail yang sangat terperinci (Sasser, 2014). Panorama realisme magis ini perlu disertakan deskripsi garis waktu, juga mengapa dan bagaimana realisme magis dapat tercipta dalam narasi.

Seli tidak hanya mampu memancarkan petir biru, ia juga mampu melakukan telekinesis. Telekinesis yang dilakukan Seli merupakan perluasan kemampuan dari kemampuan magis awalnya untuk memancarkan petir biru. Tere Liye tidak hanya terfokus pada kemampuan Seli untuk memancarkan petir biru, kemampuan magis Seli memiliki begitu banyak lapisan yang menyebabkan panorama karakternya semakin meluas namun tetap terperinci dengan dituliskannya asal usul karakternya.

Ali

Ali adalah seorang remaja berusia lima belas tahun dari Klan Bumi. Klan Bumi merupakan satu-satunya klan yang tidak mengerti keberadaan dunia paralel. Klan Bumi terkenal dengan keterbatasan ilmu pengetahuan mereka, namun Ali merupakan tokoh yang paling pintar di antara dua tokoh utama lainnya. Hal tersebut dinyatakan dalam kutipan narasi berikut.

“'Kalian tahu, ini keren. Bahkan Einstein tidak pernah bisa membayangkan ada dunia paralel di sekitarnya. Dia hanya bisa menjelaskan bahwa waktu bersifat relatif. Einstein mungkin saja benar, imajinasi adalah segalanya, lebih penting dibanding ilmu pengetahuan. Tetapi menyaksikan sendiri semua ini, mengetahui pengetahuan tersebut, lebih dari segalanya." Ali nyengir." (Liye, 2014:178) 
Ali yang pada narasi tersebut sedang berada di dunia paralel berusaha menyangkutpautkan keberadaanya di tempat magis tersebut dengan sebuah teori relativitas waktu milik Einstein. Namun alasan di balik adanya dua dunia yang hidup saling berdampingan tanpa bersentuhan tersebut masih belum terjawab karena pada dasarnya segala hal yang magis tidak dapat dijelaskan melalui perspektif ilmiah.

Realisme magis merupakan sebuah aksi pendekatan terhadap kenyataan yang jarang dirasakan dan dilihat oleh subjek di tempat atau waktu yang berbeda (Arva, 2008). Ali yang seumur hidupnya tumbuh di dunia Klan Bumi tanpa mengetahui keberadaan dunia paralel, sangat takjub ketika ia pergi menuju dunia Klan Bulan. Tidak hanya mengunjungi dunia paralel, hal lain yang menciptakan unsur realisme magis dalam narasi adalah ketika Ali menyaksikan dan menciptakan fenomena magis. Meskipun Ali menyaksikan kedua temannya, Raib dan Seli, menciptakan fenomena magis di dunia Klan Bumi tempat ia tinggal, hal ini masih tergolong kenyataan baru karena Ali tidak mengetahui fakta bahwa kedua temannya memiliki "akses" menuju dunia magis.

Walaupun Ali seorang Klan Bumi, namun ia juga memiliki kemampuan magis. Berbeda dengan kedua temannya, Ali dapat berubah menjadi beruang raksasa yang dibuktikan dalam kutipan narasi berikut.

"Ali, tubuh Ali membesar berkali-kali lipat. Dia meraung lagi, lebih kencang dan mengerikan, membuat dinding ruangan bergetar. Tangannya membesar, kakinya membesar, dan seluruh tubuhnya dibungkus dengan cepat oleh bulu tebal berwarna hitam.

Hanya dalam hitungan detik, Ali berubah menjadi beruang dengan tinggi badan menyentuh langit-langit ruangan. Kuku-kuku panjang dan tajam muncul. Tangannya bahkan sebesar orang dewasa. Matanya merah. Taring berlumuran ludah keluar dari mulutnya." (Liye, 2014:364)

Tamus, tokoh antagonis dalam novel Bumi, sebelumnya telah mengatakan bahwa Klan Bumi tidak memiliki kemampuan-kemampuan khusus seperti klan-klan lainnya, namun dalam kutipan narasi di atas Ali membuktikan bahwa Klan Bumi juga memiliki kemampuan khusus. Dalam novel, transformasi Ali menjadi beruang raksasa dan keberadaannya sebagai Klan Bumi yang dikenal tidak memiliki kemampuan khusus dikaitkan dengan tingkah laku ikan buntal. Jika ikan buntal dalam situasi terancam oleh musuh, maka ia menggandakan ukuran tubuhnya berkali-kali lipat untuk melawan ancaman yang ia hadapi, begitu pula yang dihadapi Ali ketika merasa terancam oleh portal Buku Kematian yang dibuka oleh Tamus. Jika Ali memang benarbenar seorang Klan Bumi dan ia memiliki kemampuan untuk berubah menjadi seekor beruang yang sangat besar, maka pernyataan itu menimbulkan sebuah pertanyaan bahwa selama ini telah terjadi hal-hal magis di Bumi jauh sebelum Raib, Seli, dan Selena tinggal di dunia Klan Bumi.

Elemen "ajaib" dari realisme magis tidak terletak pada realitas sehari-hari, tetapi dalam perpaduan antara mimpi dan elemen-elemen irasional (Kluwick, 2011). Mimpi dalam konteks elemen "ajaib" ini adalah sebuah pemikiran tentang hal-hal yang berkontradiksi dengan kenyataan. Seseorang seringkali memimpikan suatu hal atau peristiwa yang sangat ia nantikan untuk terjadi, namun harapan dalam mimpi itu seringkali bertolakbelakang dengan kenyataan. Sebagai contoh, jika seseorang telah menonton film mengenai karakter-karakter yang memiliki kemampuan unik, seperti dapat terbang atau memancarkan api, maka secara tidak langsung alam bawah sadarnya bertanya-tanya mengenai kemungkinan untuk memiliki kemampuan- 
kemampuan irasional tersebut, kemudian rasa keingintahuan tersebut terus menetap di alam bawah sadarnya hingga terbawa ke alam mimpi. Dapat dikatakan bahwa mimpi merupakan kumpulan ide hal-hal irasional yang dipertanyakan dan diinginkan keberadaannya untuk benar-benar hadir, maka perpaduan mimpi dan elemen irasional mampu menciptakan elemen "ajaib" yang disebut realisme magis. Pada awal narasi dalam novel, Ali dikisahkan sebagai remaja Klan Bumi biasa yang tidak memiliki kemampuan magis seperti kedua temannya, namun Tere Liye memutuskan untuk memperluas panorama karakter Ali dengan menambahkan perpaduan mimpi dan elemen irasional dalam karakternya.

\section{Simpulan}

Realisme magis adalah sebuah narasi yang memadukan unsur fantasi dan realita. Realisme magis dapat dipahami sebagai genre fiksi suatu karya sastra yang mengangkat unsurunsur di luar nalar manusia atau hal-hal magis yang berpadu dengan dunia nyata. Elemen magis dalam irreducible element dikategorikan berdasarkan objek magis, bunyi magis, tempat terjadinya peristiwa magis, dan karakteristik tokoh yang memiliki suatu kemampuan khusus yang bertolak belakang dengan nalar manusia. Narasi irreducible element dalam novel Bumi karya Tere Liye berkaitan dengan karakteristik teori realisme magis irreducible element milik Wendy B. Faris, selain itu dalam novel ini juga menunjukkan keberadaan hal-hal yang bertolak belakang dengan logika, seperti kemampuan magis para karakter, objek-objek magis, dan eksistensi dunia paralel. .

Tokoh-tokoh utama dalam novel Bumi memiliki kemampuan-kemampuan khusus yang unik dan berbeda satu sama lain, seperti Raib yang dapat berubah menjadi tak kasat mata, Seli yang dapat memancarkan petir biru, dan Ali yang dapat bertransformasi menjadi beruang raksasa. Dikisahkan bahwa Raib, Seli, dan Ali tidak sengaja memasuki dunia milik Klan Bulan melalui lorong berpindah. Lorong berpindah berperan sebagai pintu di sekat antar dua dunia tersebut. Jika lorong berpindah tidak ada, maka tidak terjadi peristiwa magis berupa terbukanya sekat antar dua dunia tersebut. Objek magis merupakan hal yang sangat sakral dan penting dalam proses terjadinya peristiwa magis karena objek magis mampu memecah batas antar dua dunia tersebut.

Dalam realisme magis, terjadi peleburan antara dua hal yang saling bertentangan. Salah satu bukti secara abstrak adanya kontradiksi antara dua hal dalam novel Bumi adalah kedua kucing milik Raib, Si Hitam dan Si Putih. Si Hitam dan Si Putih merupakan bukti dari khayalan dan kenyataan menurut sudut pandang Raib. Sedari dulu kedua orang tua Raib hanya mengetahui bahwa Raib hanya memiliki satu kucing, yakni Si Putih. Si Putih memiliki warna bulu putih dengan bintik-bintik hitam, maka ketika Raib yang ketika itu masih berusia 9 tahun menyebutkan Si Hitam dan Si Putih kepada kedua orang tuanya, mereka berasumsi bahwa Si Hitam hanyalah khayalan dari anak mereka. Kedua orang tua Raib tidak bisa melihat keberadaan Si Hitam, hanya Raib yang dapat melihatnya karena Si Hitam merupakan bagian dari dunia Klan Bumi, begitu pula Raib.

\section{Daftar Rujukan}

Arva, EL. (2008). Writing the vanishing real: Hyperreality and magical realism. Journal of Narrative Theory, $38(1)$.

Bowers, M.A. (2004). Magic (al) realism: The new critical idiom. Oxfordshire, United Kingdom: Routledge.

Chanady, A.B. (2019). Magical realism and the fantastic: Resolved versus unresolved Antitomy. New York, United States: Routledge. 
Dewi, O.K.K. (2013). Struktur dan makna cerpen fantastik dalam kumpulan cerpen Dunia di Dalam Mata. Skriptorium, 2(2).

Faris, W.B. (2004). Ordinary enchantments: Magical realism and the Remystification of Narrative. Tennessee, United States: Vanderbilt University Press.

Hart, S.M. \& Ouyang, W. (2005). A companion to magical realism. Suffolk, United Kingdom: Tamesis Books.

Hasanah, F., Mega S., \& Vincentia T. H.. (2018). Makna realisme magis dalam novel Jours de Colère dan 'Enfant Méduse karya Sylvie Germain. Jurnal Penelitian Bahasa, Sastra, dan Pengajarannya, 17(3).

Junus, U. (1986). Sosiologi sastra: Persoalan teori dan metode. Kuala Lumpur, Malaysia: Dewan Bahasa dan Pustaka Kementerian Pelajaran Malaysia

Kapitan, Y.J, Titik H., \& Imam A. B. (2018). Pengembangan bahan ajar menulis teks cerita fantasi bermuatan nilai pendidikan karakter di kelas VII. Jurnal Pendidikan: Teori, Penelitian, dan Pengembangannya, 3(1).

Kluwick, U. (2011). Exploring magic realism in Salman Rushdie's Fiction. New York: Routledge

Liye, T. (2014). Bumi. Jakarta, Indonesia: PT Gramedia Pustaka Utama.

Perez, R. \& Chevalier, V.A. (2014). The Palgrave handbook of magical realism in the twenty-first century. Illinois, United States: Northwestern University Press.

Sari, R.A. (2018). Narasi realisme magis dalam Novel Puya ke Puya karya Faisal Oddang: Konsep karakteristik Realisme Magis Wendy B. Faris. Jurnal Sapala, 5(1).

Sasser, K.A. (2014). Magical realism and cosmopolitanism: Strategizing belonging. New York, United States: Palgrave Macmillan.

Sie, H. (2020). Realisme magis dalam novel Seratus Tahun Kesunyian karya Gabriel Garcia Marquez berdasarkan konsep Karakteristik Realisme Magis Wendy B. Faris. Skripsi. Maumere, Indonesia: Sekolah Tinggi Filsafat Katolik Ledalero.

Srikanth, R. (2014). Elements of magical realism: A reading of Garcia Marquez's One Hundred Years of Soliture and Salman Rushdies' Midnight's Children. International Journal of English Language, Literature and Humanities, 2(1).

Warnes, C. (2009). Magical realism and the postcolonial novel: Between faith and irreverence. Hampshire, United Kingdom: Palgrave Macmillan. 